\title{
Gender and the Civil War: A Review Essay
}

\author{
LESLIE A. SCHWALM
}

Gender and the Sectional Conflict, by Nina Silber. The Steven and Janice Brose Lectures in the Civil War Era. Chapel Hill: University of North Carolina Press, 2008. xxi, 117 pp. Illustrations, notes, index. \$24.95 cloth.

Army at Home: Women and the Civil War on the Northern Home Front, by Judith Giesberg. Civil War America Series. Chapel Hill: University of North Carolina Press, 2009. xi, 232 pp. Illustrations, graphs, notes, bibliography, index. $\$ 35.00$ cloth.

Considered in tandem, these new additions to the study of the Civil War brightly illuminate the impact of ideas about gender on what Northerners and Southerners believed they fought for, as well as on their experience and memory of the war. Both authors demonstrate why the deep influence of gender ideology on American cultures and societies must be a central consideration in studying how soldiers or civilians understood the conflict, how wartime societies responded to women's patriotism, how the war affected the home front, and how the nation remembered and memorialized the conflict. Gender ideologies the elaborate sets of ideas about how men and women should act, their appropriate arenas of activity, and their relationship to the state - so thoroughly shaped the nineteenth-century world of thought and action that we disregard them at peril of missing a core element of how men and women understood themselves and each other as well as their experience of the war.

THE ANNALS OF IOWA 69 (Summer 2010). (C) The State Historical Society of Iowa, 2010. 
In engaging these topics, Silber's Gender and the Sectional Conflict is a significant, useful, and insightful synthesis of more than two decades of scholarship, but it is just as valuable for pushing at the boundaries of our knowledge about how gender ideology shaped American politics and culture. Consisting of a substantial preface and three essays based on a series of invited lectures at Penn State's Richards Civil War Center, Silber's book is a particular scholarly art form; don't expect extensive new archival research, but rather look for thoughtful, probing mediations that offer unusual and engaging transparency to the historian's process of building on and leaping off the work of others.

Both the Confederacy and the Union widely deployed visual and rhetorical imagery of mothers and wives demanding and consenting to men's military service; the same imagery was commonly found in soldiers' letters home. Much of Silber's book explains and explores why there were such deep sectional differences in how soldiers understood this gendered imagery. Confederate soldiers were literally as well as figuratively fighting to defend their homes (and their mastery over those households and household dependents); Union soldiers were far more likely to understand their fight as one they entered on behalf of "the state" despite their familial obligations. Silber shows how the Northern political economy contributed to the familiarity of this distinction for Northern men. Northern men were increasingly propelled into a public market economy where they labored for wages, while their wives' contributions to their families - still essential to their economic survival - became increasingly privatized and distanced from the public sphere, and therefore the state. Furthermore, Silber shows why Union men could envision a relationship to the nation-state - because it materialized more frequently in the lives of Northerners (she usefully cites greater rates of public school attendance in the North as one example and state- and locally funded relief during the war as another). In contrast, the "nationalist imagination" of Southern men was far more limited - in part because of their fewer opportunities to interact with a public state, but also because the household took a central place in the Southern political imagery.

Silber's second essay moves from the symbolic uses and meanings of womanhood during the war to considering the 
consequences when women in both regions entered into wartime activism - both as patriots and as dissenters. Union women, Silber points out, enjoyed a physical distance from the battlefield and from the kinds of material sacrifices that more closely linked Confederate women with their nation's cause. In turn, this regional distinction meant that Confederates and Unionists alike romanticized Confederate women as more devoted to their cause and more united in their patriotic devotion (and fury). Northern women were, in fact, active in many instances of antiwar, antidraft, antigovernment activities, but Silber also finds them notably more vulnerable to charges of deficient patriotism because of the proscribed and ideological distance of the private domestic sphere from the public realm of the nationstate. When Union women crossed that divide and assumed themselves to be individual actors in relation to the state (rather than simply echoing the political beliefs of fathers and husbands), they entered an unchartered territory of female citizenship.

Carrying her central concern with how ideologies of gender helped constitute the way the war was experienced and remembered, Silber's third essay contrasts the work of memorialization among Northern and Southern women after the war. If this essay is less adventurous than those that precede it, it continues in the same spirit: focusing primarily on the North, but skillfully using regional and national comparisons to draw out divergent gendered meanings and repercussions of the war North and South.

In contrast to Silber's smart and largely synthetic work, Judith Giesberg's Army at Home draws on extensive archival research to produce an exciting, pathbreaking social history of the North's war at home. Giesberg reveals the experiences and challenges encountered by Northern working-class women a population whose wartime experience has been largely overlooked, since most of the histories of gender and the war have focused on the middling classes. Particularly when read alongside Silber's book, Giesberg's study allows us to see more of the material impact of war; we move from Silber's probing of the uses of ideas about gender during times of war to urban and rural women's efforts to cope with the poverty, displacement, and dangerous new workplaces created by war. One of the remarkable features of Giesberg's study is its range: individual 
chapters move from Philadelphia to San Francisco, from war widows to African American women challenging Jim Crow streetcars, from the victims of horrible accidents in the arsenals where they worked to struggling farm women and mothers coping with homelessness. As persuasive as Silber's treatise is about how gender shapes culture, Giesberg's work leaves no room for doubt that the war dramatically altered the daily lives of working-class women, urban and rural, as well as the form and location of women's political engagement. As they took over farm management and operations, made demands on the state for relief, challenged the men supervising their dangerous labor at arsenals, and sought to retrieve the bodies of their loved ones from battlefields, working-class women made new demands on the state, challenged presumptions of female passivity, and claimed new public voices - becoming politically engaged in new spaces and new ways. Army at Home thus brings flesh and blood to the more culturally engaged work of Gender and the Sectional Conflict.

There is much that is new in Giesberg's account, including her exploration of African American women's challenge to the segregation of urban space. Giesberg reveals the nuanced political terrain of black women's battles against streetcar segregation in wartime Philadelphia and San Francisco. More than any of the scholars who have previously (and most only briefly) studied the wartime upswelling of this civil rights struggle, Giesberg demonstrates its connection to wider activism among African American women. Their wartime work on behalf of black soldiers in black hospitals, schools, and contraband camps required daily travel across city landscapes, typically without the protective accompaniment of a male companion. Alone and accosted by hostile streetcar drivers and white passengers, African American women courageously chose to place their own bodies on the line when they challenged the proscriptions that were designed to regulate black women's use of streetcars. When they then took their demand for equal rights into the courtroom, they extended the impact and consequences of their demands for a new conception of citizenship; filing suit on their own behalf, African American women construed and demanded a direct and unmediated relationship with the state. 
Both of these works, while smart, nuanced, and strikingly original, share with most studies of the war a failure to grapple with gender as a raced ideology for white Americans. Although Giesberg significantly and Silber only peripherally grapple with African American women's wartime experience, neither historian addresses the war's substantial impact on the prerogatives or anxieties that Northern women and men experienced as whites. Yet this same war that so dramatically altered the status of African Americans, men and women, also changed forever what it meant to be white in a nation that no longer offered political, legal, and military protections for black slavery - and white mastery. That is one of the boundaries in our knowledge of the war that gender historians must ultimately grapple with: the mutually informed rhetorics of race and gender that meant womanhood was never idealized without a racial component, and black men and women were rarely insulted without a gendered element to that assault. Wartime political rhetoric, as well as the political economies of the plantation South and the rigidly segregated North, were shaped by gendered rhetorics that were deeply influenced by race. Social and cultural historians alike still have their work cut out for them, but these books by Silber and Giesberg will prove indispensible to their endeavor. 